\title{
Investigation of Hydraulic Properties of Soils Varying in Texture, Organic Carbon and Soluble Salt Contents of Arid and Semi-arid Regions
}

\author{
Seema*, Rita Dahiya and V.K. Phogat \\ Department of Soil Science, CCS Haryana Agricultural University, Hisar-125004, India \\ *Corresponding author
}

\section{Keywords}

Hydraulic

conductivity, Soil moisture at field capacity, Soil moisture at permanent wilting point, Soil organic carbon

Article Info

Accepted:

20 March 2019

Available Online:

10 April 2019

\section{A B S T R A C T}

Hydraulic properties of soils play a significant role in development and adoption of suitable water management practices capable of increasing input use efficiency of soils for maintaining agricultural production of arid and semi arid regions. The study was carried out to investigate the hydraulic properties of soils varying in texture, organic carbon and salt contents. The soil samples were collected from 0-15 and 15-30 cm depths at farmers' field in different villages spread over nine districts of the Haryana state during 2016-17. The experimental soils were found to belong to six textural classes i.e., sand, loamy sand, sandy loam, loam, silty loam and sandy clay loam having silt + clay content from 6- $40 \%$. The organic carbon (OC) content, electrical conductivity, $\mathrm{pH}$, saturated hydraulic conductivity (Ksat), sodium adsorption ratio, moisture at field capacity and permanent wilting point soils were determined using standard methods. The Ksat of the soils was found of to be significantly and exponentially positively correlated with bulk density $\left(\mathrm{R}^{2}=\right.$ $0.61)$ and negatively correlated with silt+clay content $\left(R^{2}=0.90\right)$ at $0-15$ and $15-30 \mathrm{~cm}$ depths. The Ksat had significant and exponential negative correlation with soil $\mathrm{OC}$ at $0-15$ $\mathrm{cm}\left(\mathrm{R}^{2}=0.83\right)$ and $15-30 \mathrm{~cm}\left(\mathrm{R}^{2}=0.66\right)$ in the present study. The soil moisture at field capacity (FC) and permanent wilting point (PWP) were observed positively correlated with silt+clay content with $\mathrm{R}^{2}$ value of 0.87 and 0.85 , respectively. The moisture at FC and PWP were found to be significantly and positively correlated with soil organic carbon content with $R^{2}=0.85$ and 0.76 , respectively, at $0-15 \mathrm{~cm}$ depth. However, moistures at FC and PWP showed significant and negative correlation with bulk density at both the depths. Maximum water holding capacity of soils was observed higher with increase in silt+clay content and lower with increase in bulk density at both the depths. The $\mathrm{pH}_{1: 2}$ and $\mathrm{EC}_{1: 2}$ of the soils were found in range of $6.69-8.08$ and $0.11-3.68 \mathrm{dS} / \mathrm{m}$, respectively. However, no significant correlation was observed between hydraulic properties and soluble salt concentration. The results of the study and relationship of hydraulic properties with the physical properties of the soils indicated that knowledge of hydraulic properties of the soils is pre-requisite for adopting efficient water management practices in arid and semi-arid regions of the Haryana state for maintaining the sustainable crop production. 


\section{Introduction}

India is an agrarian country and about $60 \%$ of the Indian population residing in rural areas still depends primarily on agriculture for their livelihood with 82 percent of farmers being small and marginal. In 2017-18, total food grain production was estimated at 275 million tonnes (MT). The Haryana state is now a leading contributor to the country's food production as agriculture is the principal occupation of the residents of the state. Total cultivable area of the Haryana state is 3.757 mha, out of which net irrigated area is 2.974 mha. The major irrigation sources are canal irrigation (1.15 mha), and remaining areas are under groundwater irrigation which is mainly $(54 \%)$ brackish in nature. Present scenario of water scarcity, especially in arid and semiarid regions of the state requires a strategy for efficient use of water for sustaining agricultural production (Fereres and Soriano, 2007) and necessitates for quantitative assessment of hydraulic properties of soils of arid and semi-arid regions. The hydraulic properties play crucial role in adoption of appropriate water management practices for enhancing water use efficiency as well as alleviating production constraints of the soils. The hydraulic properties include both water retention and water transmission characteristics of soils. Water retention properties involve saturation capacity, field capacity, permanent wilting point, plant available water, etc., while water transmission properties include hydraulic conductivity, infiltration, percolation, etc. Soil water retention curve plays key role in soil and water management practices. Hydraulic properties of soils such as water infiltration, hydraulic conductivity, and water retention regulate the ability of the soil to capture and accumulate precipitation or irrigation water. Saturated hydraulic conductivity (Ksat), which determines the capacity of a soil to conduct water in soil, and plays important role in soil-plant-water processes, is one of the highly dynamic soil properties. It strongly depends on soil pore geometry which is highly variable in nature depending upon soil texture and structure, and other soil properties and various factors (Deb and Shukla, 2012). Hence, saturated hydraulic conductivity $\left(\mathrm{K}_{\text {sat }}\right)$ of different soils under variable field conditions is still a matter of interest (Jarvis $e t$ al., 2013; Papanicolaou et al., 2015). Jarvis et al., (2013) reported that $\mathrm{K}_{\mathrm{sat}}$ in the topsoil $(<30 \mathrm{~cm})$ was found to be strongly dependent on soil bulk density and organic carbon content. However, such findings are not consistent across soils and climates, therefore, many workers have suggested (Singh et al., 2014) the need for better understanding of hydraulic properties of soils in different regions. The $\mathrm{K}_{\mathrm{sat}}$ of the sand (having large sand fraction) was observed more than that of the clay loam (having small sand fraction) soil (Reynolds, 2000). The water regime of a soil is largely affected by both the hydraulic conductivity and infiltration rate (Lal and Shukla, 2004). Water retention and transmission properties of soils are influenced by texture, structure, organic matter content, soil compaction, concentration and composition of soil solution (Hillel, 1982). Coarse-textured and well-aggregated soils are more conductive than clayey soils because of the large pore spaces (Halfmann, 2005). Hugar et al., (2012) found that organic carbon in Red soils acted as a fine medium of sorption to hold water as well as improved the soil aggregation. Soil texture controls water retention at low potentials while role of soil structure predominates at higher potentials (Nimmo, 1997). The soil moisture retention capacity was observed higher for the soils having large amount of clay and organic carbon content (Beare et al., 1994; Kar et al., 2017). The soil organic carbon (OC) content was found negatively correlated to bulk density and positively correlated to porosity of soil (Rawls et al., 2005). The soil organic 
carbon also affects the water retention properties of soils. At low carbon contents, an increase in carbon content led to an increase in water retention in coarse soils and to decrease in water retention in fine-textured soils whereas, at high carbon contents, increase in carbon contents resulted in an increase in water retention of all textured soils (Rawls et al., 2003). With organic material addition, bioavailable nutrition elements significantly enhance the microbial activities and consequently favor the soil aggregate formation and stability (Downie et al., 2009). In addition to these properties, the presence of excess of salts and their composition may also influence water retention and release of water in soil, its movement in soil and ultimately affect the crop yield. Presence of high sodium concentration in soil resulted into decrease in $\mathrm{K}_{\text {sat }}$ of soils whereas magnesium ions concentration did not have any effect on hydraulic properties (Singh et al., 2011). Arid and semi-arid areas especially characterized by salinity problems have a long-term limiting factor to the crop production. Hence, the study of water transmission properties of these soils is prerequisite for their reclamation and use for crop production. The pedotransfer functions (PTFs) are often used to estimate hydraulic properties using readily available soil properties (Vereecken et al., 1990; Leij et al., 2004). However, the applicability of PTFs is restricted as soil conditions generally differ from those under which PTFs were derived (Cornelis et al., 2001; Lee, 2005). The simulation of hydraulic properties offers other alternatives, but soil hydrological behavior on large areas may show high spatial and temporal variability and requires adequate data sets of soil hydraulic properties. Thus, laboratory measurements are more prevalent for determination of hydraulic properties on large scale representing heterogeneity of the medium being studied (Basile et al., 2006) which requires extended time for their accurate measurement. The adequate information on the effect of soil texture, organic matter and salt contents on hydraulic properties of soils of Haryana state is not available. Keeping in view the significance of hydraulic properties, the study was carried out to investigate (i) effect of texture, organic carbon content, concentration and composition of soluble salts on hydraulic properties of soils (ii) relationships between hydraulic properties and physico-chemical characteristics of soils.

\section{Materials and Methods}

\section{Sampling locations}

Soil samples at 0-15 and $15-30 \mathrm{~cm}$ soil depths were collected from 20 locations at farmers' fields in villages viz., Balsmand, Shahzadpur, Narnaund, Kharia, Ladwa, Zandlin Kalan, Bata, Zafira Viran, Ghella Khera, Uchani, Ujina, Ramayan, Begu, Berpura, Shahpur, Nai, Kyudak, Byana khera, Sohana, Sink from nine districts of the Haryana State (Fig. 1).

\section{Analysis of physico-chemical properties of soil}

The soil samples taken with auger were dried, ground and passed through sieve for analysis of soil samples for mechanical composition of soils (Table 1) determined by international pipette method (Piper, 1966). The soil samples were collected from each experimental site using galvanized iron cores (internal diameter $=5 \mathrm{~cm}$ and height $=5 \mathrm{~cm}$ ) at both 0-15 and 15-30 $\mathrm{cm}$ depths were used for determination of bulk density. The soil cores (metallic) were saturated overnight for determination of saturated hydraulic conductivity using constant head method (Richards, 1954) in the laboratory using the following equation according to Darcy law:

$\mathrm{q}=\mathrm{Q} / \mathrm{A}=-\mathrm{K}(\Delta \mathrm{H}) / \mathrm{L}$ 
Where $\mathrm{q}$ is the water flux $\left(\mathrm{cm} \mathrm{hr}^{-1}\right)$; $\mathrm{Q}$ is the volume of water vertically flowing through a saturated soil column of length $L(\mathrm{~cm})$ with a cross sectional area of $A\left(\mathrm{~cm}^{2}\right), K$ is saturated hydraulic conductivity, and $\Delta \mathrm{H} / \mathrm{L}$ represents the total hydraulic head gradient. The maximum water holding capacity of soils was determined using keen's box method. Soil moisture characteristic curves were obtained by measuring the water content of soil samples at $0.1,0.3,0.5,1.0,3.0,5.0$ and 15.0 bar pressure using pressure plate apparatus (Richards, 1954). The soil core samples were saturated overnight placed in contact on a saturated pressure plate and brought to equilibrium at $0.1,0.3,0.5,1.0,3.0$, and 5.0 bar using the pressure plate apparatus. To obtain the soil water content at 15 bar, saturated soil was transferred to retainer rings on a saturated pressure plate of the pressure plate apparatus. The soil samples were equilibrated at 15 bar and when water flow ceased through the outflow tube at equilibrium, at each pressure the soil water content was determined gravimetrically. The volumetric water content was obtained by taking the product of gravimetrical water content and bulk density of the respective sample. The dried and ground soil samples were passed through $0.5 \mathrm{~mm}$ sieve for determination of soil organic carbon content using wet digestion method (Walkley and Black, 1934). For determination of EC and $\mathrm{pH}$ of soil, soil water suspension of 1:2 was prepared with distilled water. The soil suspension was stirred intermittently for about 30 minutes and then allowed to stand until clear supernatant is obtained. Meanwhile, the conductivity meter was calibrated with 0.01 $\mathrm{M} \mathrm{KCl}$ solution and $\mathrm{pH}$ meter was calibrated with buffer solution of $\mathrm{pH}$ value 7.0 and 9.2. The SAR of soil samples was determined by measuring the water soluble sodium, calcium and magnesium using standard methods. The sodium concentration was determined by equilibrating the soil with neutral $1 \mathrm{~N}$
$\mathrm{NH}_{4} \mathrm{OAC}$ with the help of flame photometer. The $\mathrm{Ca}$ and $\mathrm{Mg}$ in the soil samples were determined by Versenate titration method. The sodium adsorption ratio was calculated by the formula:

$$
S A R=\frac{\mathrm{Na}^{+}}{\sqrt{\frac{1}{2}\left(\mathrm{Ca}^{2+}+\mathrm{Mg}^{2+}\right)}}
$$

where, concentrations of water soluble $\mathrm{Na}^{+}$, $\mathrm{Ca}^{2+}$ and $\mathrm{Mg}^{2+}$ are expressed in me/L.

\section{Results and Discussion}

\section{Relationship between hydraulic properties and mechanical composition}

The experimental soils collected from different sites (Table 1) were found to belong to six textural classes i.e., sand, loamy sand, sandy loam, loam, silty loam and sandy clay loam on basis of mechanical composition. The silt + clay content of the soils ranged from $6-44 \%$. The saturated hydraulic conductivity $\left(\mathrm{K}_{\mathrm{sat}}\right)$ of the soils was found to be significantly negative and exponentially correlated with the silt + clay contents of soils with $\mathrm{R}^{2}$ value of 0.90 (Fig. $2 a$ ) at both $0-15$ $\mathrm{cm}$ and $15-30 \mathrm{~cm}$ depths. With increase in silt + clay content of soils, decrease in the mean pore size diameter resulted in decrease of $\mathrm{K}_{\mathrm{sat}}$ of the soils. Shewtha and Varija (2015) observed similar results and recorded highest saturated hydraulic conductivity of sandy soils ( 13.92 to $6.48 \mathrm{~cm} / \mathrm{hr}$ ) followed by loamy sand and sandy loam soils. The soil moisture at field capacity (FC) increased with increase in fine fractions of the soils (0-15 and 15-30 $\mathrm{cm}$ depth) and had significant and positive linear correlation with silt + clay content of the soils with $\mathrm{R}^{2}$ value of 0.87 (Fig. $2 b$ ). The moisture at permanent wilting point (PWP) also followed similar trend and found significantly positive and linearly correlated with silt + clay content having $\mathrm{R}^{2}$ value of 
0.85 (Fig. 2c). The increase in soil moisture at field capacity with increase in silt + clay content of soil is attributed to increased volume of micro pores capable to hold water at soil water potential of -0.3 bar and increased specific surface area contributing to adsorption of more amount of water at permanent wilting point at soil water potential of -15 bar. Correlation matrix among saturated hydraulic conductivity, soil moisture at FC and textural fractions of the experimental soils is presented in Table 2 . Shewtha and Varija (2015) demonstrated soil texture as dominant factor controlling water retention particularly at high suctions. The data on maximum water holding capacity (MWHC) at 0-15 and 15-30 cm also showed positive and linear correlation with silt + clay content of soils with $\mathrm{R}^{2}$ value of 0.60 (Fig. $2 d$ ). The results indicated that with increase in fineness of soil texture due to increasing silt + clay content, the soils will have capacity to retain higher amount of water at saturation. Olorunfemi and Fasinmirin (2011) also reported that sandy clay loam soils had highest water holding capacity (36.69\%) among the sandy loam (25.15\%) and loam $(31.98 \%)$ soils.

\section{Relationship between hydraulic properties and bulk density}

The relationship between $\mathrm{K}_{\mathrm{sat}}$ and bulk density of texturally different soils at different depths $(0-15$ and $15-30 \mathrm{~cm})$ revealed that $\mathrm{K}_{\text {sat }}$ was significantly positive and exponentially correlated with the bulk density with $\mathrm{R}^{2}$ value of 0.61 (Fig. 3a). The results specify that increase in bulk density in the present study is attributed to increase in coarser sand fraction which consequently resulted in increase in mean pore size and contributed to increase in hydraulic conductivity of soils. The moisture at FC and PWP was observed significantly negative and linearly correlated with bulk density with $\mathrm{R}^{2}$ value of 0.79 and 0.63 , respectively (Fig. 3b, 3c). The decrease of soil moisture at FC with increasing bulk density of soils is mainly attributed to effect of coarse fraction on micro pores accountable for retaining water at soil water potential of -0.3 bar whereas at PWP the decrease in soil moisture might be due to decrease in specific surface area of soils, predominantly due to higher sand fraction. Dec et al., (2008) reported that water retention in soils was strongly affected by soil bulk density. The maximum water holding capacity (MWHC) of the soils also decreased with increasing bulk density and followed the significant negative and linear correlation with bulk density with $\mathrm{R}^{2}$ value of 0.89 (Fig. $3 d$ ).

\section{Relationship between hydraulic properties and soil organic carbon}

The soil organic carbon (SOC) content of texturally different soils collected from surface $(0-15 \mathrm{~cm})$ and subsurface layer (15-30 $\mathrm{cm}$ ) ranged from 0.22 to $0.72 \%$, and 0.17 to $0.59 \%$ respectively. The experimental data on Ksat and SOC contents indicated that $\mathrm{K}_{\text {sat }}$ had significant negative and exponential correlation with the SOC contents with $\mathrm{R}^{2}$ value of 0.83 at $0-15 \mathrm{~cm}$ depth and $R^{2}$ value of 0.66 at $15-30 \mathrm{~cm}$ depth (Fig. 4). The results showed that increase in soil organic carbon content, resulted in decrease of the volume of water transmitting pores in the soils and consequently decrease in $\mathrm{K}_{\mathrm{sat}}$ in the present study as majority of soils are characterized by medium to coarse texture. Yazdanpanah et al., (2016) found that soils with lower soil organic carbon compared to those with higher organic carbon resulted in higher hydraulic conductivity due to more macro pore fraction. However, the soil moisture at FC was observed significantly positive and linearly correlated with organic carbon content with $\mathrm{R}^{2}$ value of 0.85 and 0.76 at $0-15$ and $15-30$ cm depths, respectively (Fig. 5). The increase in soil moisture at FC with higher SOC 
content attributes to higher volume of water holding pores at soil water potential of -0.3 bar. Similar trends were found between PWP and SOC contents of soils (Fig. 6). The characteristics of SOC to increase the specific surface area contributed to higher soil moisture at PWP with higher SOC contents. However the effect of organic carbon content was found more pronounced at field capacity than at permanent wilting point. Kar et al., (2017) revealed that higher the clay and organic carbon content, greater was the moisture retention capacity. Rawls et al., (2003) also reported similar effects of soil organic carbon content on soil moisture retention of soils. The MWHC of the texturally different soils for both the depths was found significantly positive and linearly correlated with organic carbon contents of soils with $\mathrm{R}^{2}$ value of 0.72 (Fig. 7). The increase in water holding capacity of the soils is due to higher total porosity of soils with higher SOC. It was reported that in certain types of soil, organic matter can hold up water up to 20 times of their weight (Reicosky, 2005). Hudson (1994) observed that for each one percent increase in soil organic matter, the available water holding capacity in the soil increased by 3.7 percent.

Table.1 Mechanical composition of experimental soils collected from different locations

\begin{tabular}{|c|c|c|c|c|c|c|}
\hline \multirow{2}{*}{$\begin{array}{l}\text { Sr. } \\
\text { No. }\end{array}$} & \multirow[t]{2}{*}{ Location } & \multicolumn{2}{|c|}{$0-15 \mathrm{~cm}$} & \multicolumn{2}{|c|}{$15-30 \mathrm{~cm}$} & \multirow[t]{2}{*}{ Texture } \\
\hline & & $\begin{array}{c}\text { Sand } \\
(\%)\end{array}$ & $\begin{array}{c}\text { Silt + Clay } \\
(\%)\end{array}$ & $\begin{array}{l}\text { Sand } \\
(\%)\end{array}$ & $\begin{array}{c}\text { Silt + Clay } \\
(\%)\end{array}$ & \\
\hline 1. & Balsmand & 94 & 6 & 93 & 7 & Sand \\
\hline 2. & Shahzadpur & 96 & 4 & 92 & 8 & Sand \\
\hline 3. & Shahpur & 92 & 8 & 90 & 10 & Sand \\
\hline 4. & Narnaund & 78 & 22 & 76 & 24 & Loamy Sand \\
\hline 5. & Kharia & 81 & 19 & 80 & 20 & Loamy Sand \\
\hline 6. & Zandlin Kalan & 78 & 22 & 80 & 20 & Loamy Sand \\
\hline 7. & Nai & 80 & 20 & 76 & 24 & Loamy Sand \\
\hline 8. & Ladwa & 74 & 26 & 72 & 28 & Sandy Loam \\
\hline 9. & Kyudak & 80 & 20 & 78 & 22 & Sandy Loam \\
\hline 10. & Byana Khera & 82 & 18 & 80 & 20 & Sandy Loam \\
\hline 11. & Bata & 64 & 36 & 62 & 38 & Loam \\
\hline 12. & Uchani & 60 & 40 & 64 & 36 & Loam \\
\hline 13. & Ujina & 70 & 30 & 66 & 34 & Loam \\
\hline 14. & Ramayan & 62 & 38 & 64 & 36 & Loam \\
\hline 15. & Sohana & 70 & 30 & 72 & 28 & Loam \\
\hline 16. & Berpura & 68 & 32 & 64 & 36 & Loam \\
\hline 17. & Zafira Viran & 56 & 44 & 56 & 44 & Silty Loam \\
\hline 18. & Ghella Khera & 62 & 38 & 64 & 26 & Silty Loam \\
\hline 19. & Sink & 62 & 38 & 58 & 42 & Silty loam \\
\hline 20. & Begu & 69 & 31 & 71 & 29 & $\begin{array}{l}\text { Sandy clay } \\
\text { loam }\end{array}$ \\
\hline
\end{tabular}


Table.2 Correlation matrix among saturated hydraulic conductivity, field capacity, soil organic carbon content and other properties

\begin{tabular}{|c|c|c|c|c|c|c|}
\hline Parameter & $\begin{array}{c}\text { Ksat } \\
\left(\mathrm{cm} \mathrm{hr}^{-1}\right)\end{array}$ & $\begin{array}{l}\text { Moisture at } \\
\text { FC }(\%)\end{array}$ & Sand $(\%)$ & $\begin{array}{c}\text { Silt+clay } \\
(\%)\end{array}$ & $\operatorname{SOC}(\%)$ & $\begin{array}{l}\text { Bulk density } \\
\qquad\left(\mathrm{Mg} \mathrm{m}^{-3}\right)\end{array}$ \\
\hline Ksat $\left(\mathrm{cm} \mathrm{hr}^{-1}\right)$ & 1.000 & & & & & \\
\hline Moisture at FC (\%) & $-0.905^{*}$ & 1.000 & & & & \\
\hline Sand $(\%)$ & $0.883 *$ & $-0.933 *$ & 1.000 & & & \\
\hline Silt+clay (\%) & $-0.889 *$ & $0.933^{*}$ & $-0.998 *$ & 1.000 & & \\
\hline $\operatorname{SOC}(\%)$ & $-0.847 *$ & $0.825 *$ & $-0.765^{*}$ & $0.777^{*}$ & 1.000 & \\
\hline Bulk density $\left(\mathrm{Mg} \mathrm{m}^{-3}\right)$ & $0.878 *$ & $-0.838 *$ & $0.812 *$ & $-0.818^{*}$ & $-0.896^{*}$ & 1.000 \\
\hline
\end{tabular}

Fig.1 Location map of experimental sampling sites in villages of Haryana stat

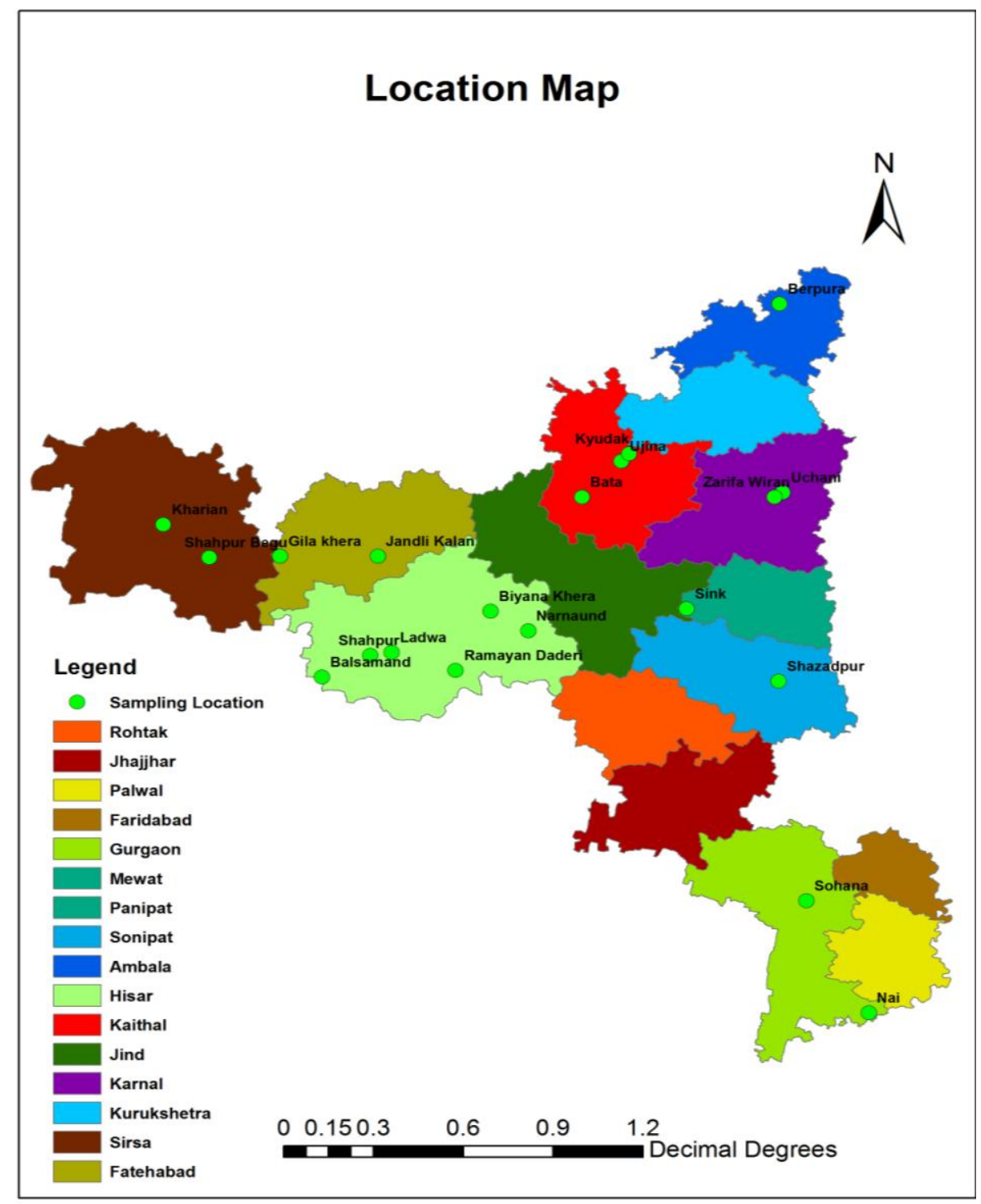


Fig.2 Relationship of (a) saturated hydraulic conductivity (b) soil moisture content at FC (c) soil moisture content at PWP and (d) maximum water holding capacity with silt + clay content of texturally different soils at 0-15 and $15-30 \mathrm{~cm}$ depths

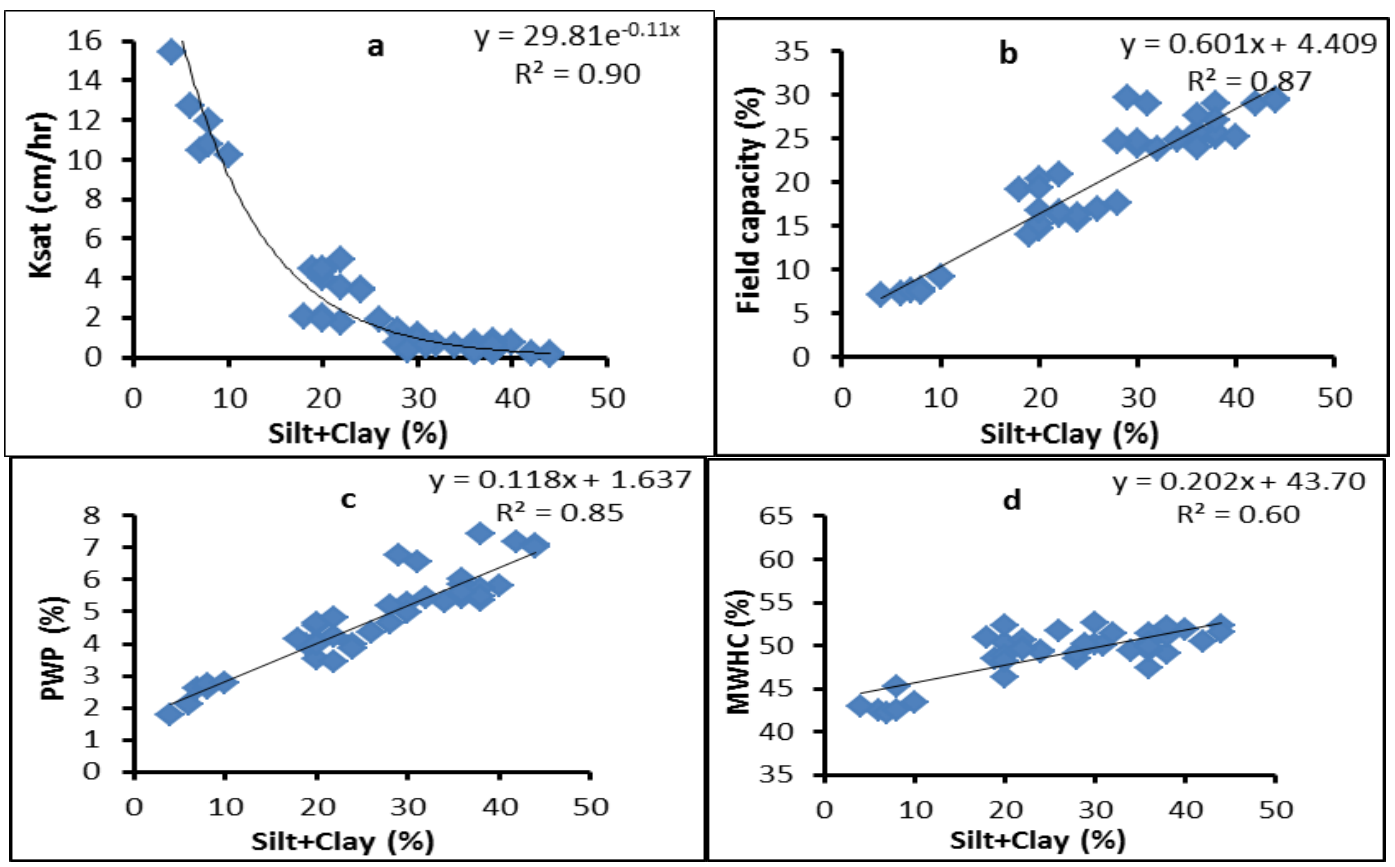

Fig.3 Relationship of (a) saturated hydraulic conductivity (b) soil moisture content at FC (c) soil moisture content at PWP and (d) maximum water holding capacity with bulk density of texturally different soils at 0-15 and 15-30 cm depths

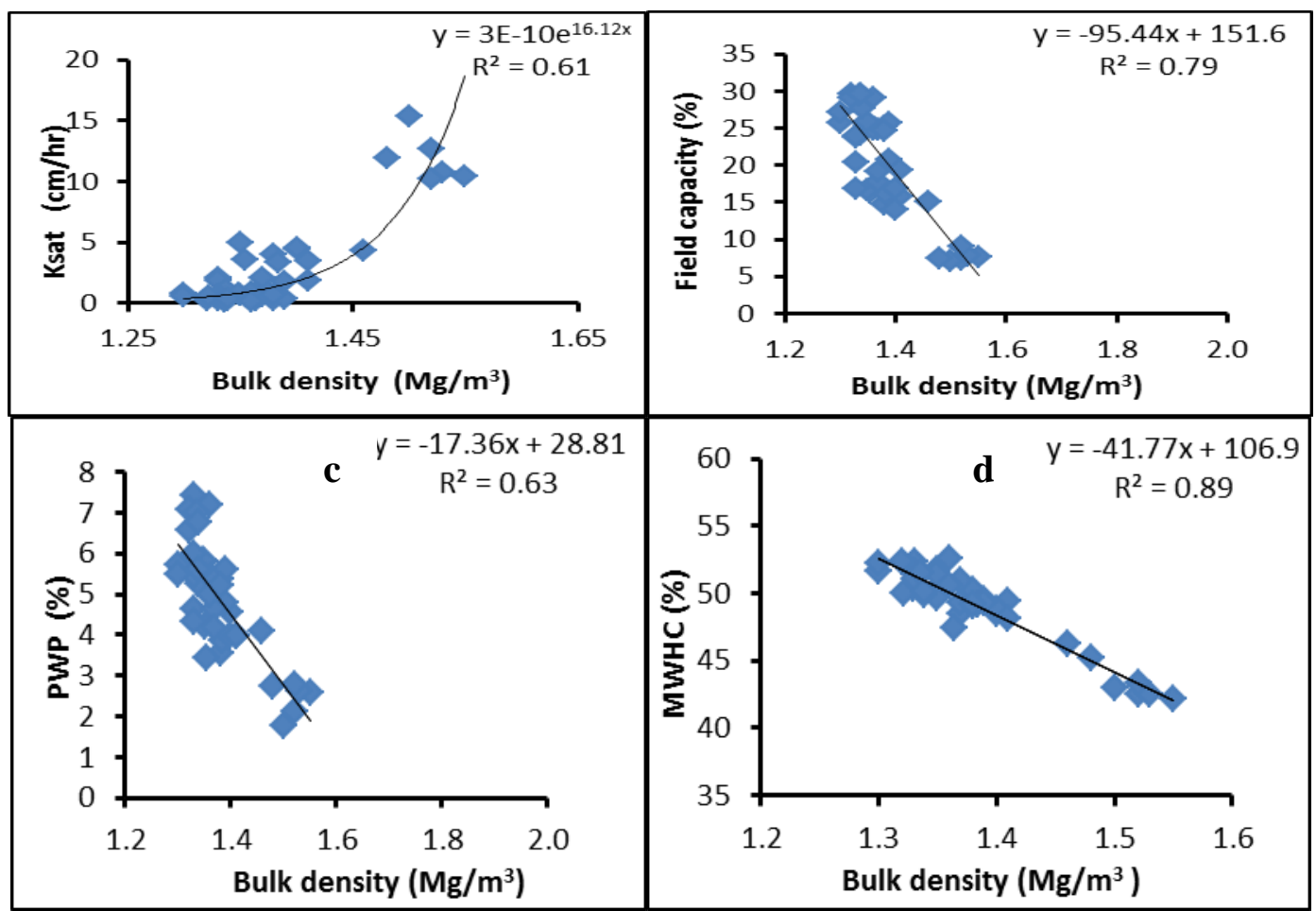


Fig.4 Relationship of saturated hydraulic conductivity (Ksat) with soil organic carbon at 0-15 and $15-30 \mathrm{~cm}$ depths

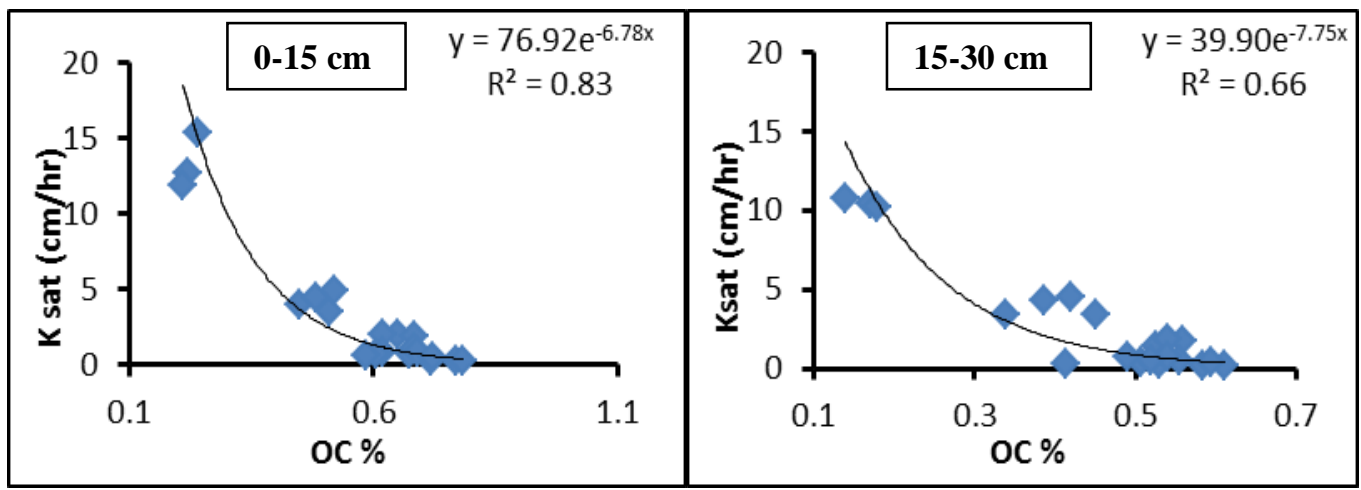

Fig.5 Relationship of soil moisture at field capacity ( 0.3 bar) with soil organic carbon at $0-15$ and $15-30 \mathrm{~cm}$ depths

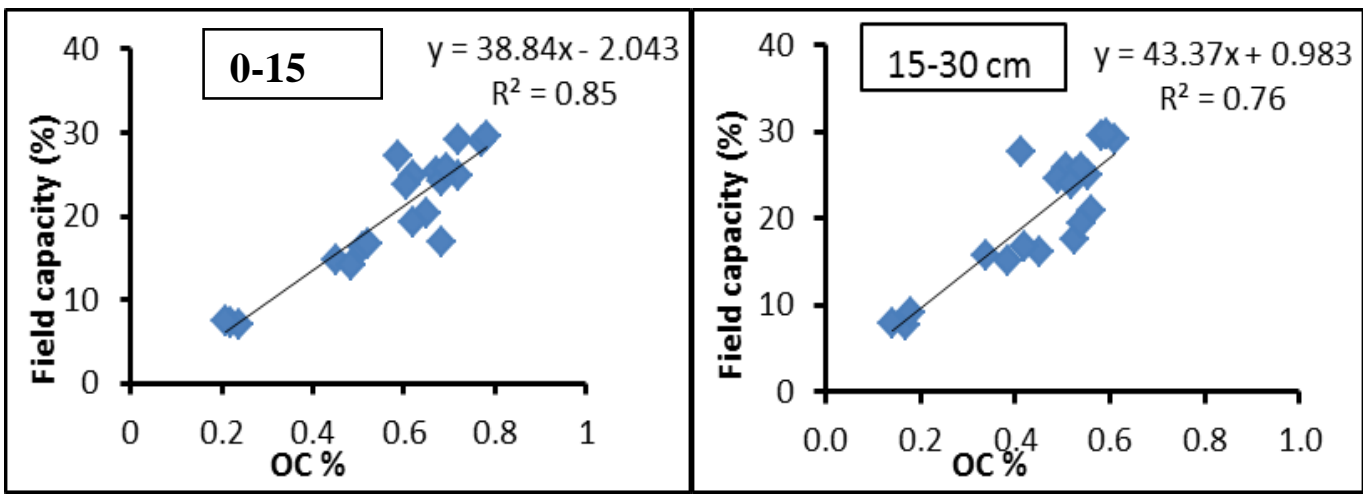

Fig.6 Relationship of soil moisture at permanent wilting point (15 bar) with soil organic carbon at $0-15$ and $15-30 \mathrm{~cm}$ depths

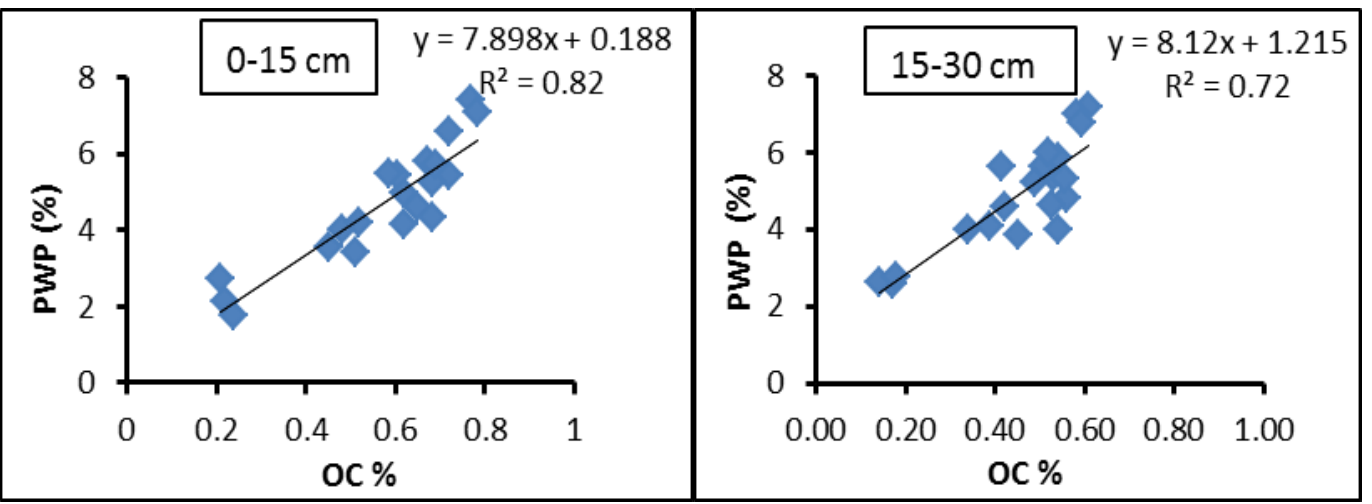


Fig.7 Relationship of maximum water holding capacity (MWHC) with soil organic carbon at 015 and $15-30 \mathrm{~cm}$ depths

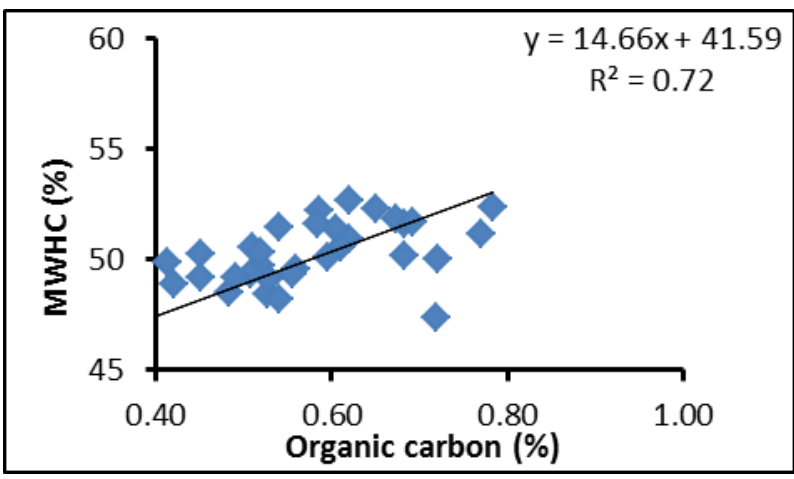

Relationship between hydraulic properties and pH, EC, SAR

The measured values of soluble salt concentration (EC), $\mathrm{pH}$ and SAR of the soil samples indicated no significant correlation with the hydraulic properties (Ksat, moisture at FC and PWP, and MWHC) of the experimental soils.

In conclusion, the soil samples were collected from twenty sites at farmers' fields in different villages spread over nine districts of Haryana state, India to investigate the hydraulic properties of soils influenced by texture, organic matter and soluble salts. The soils varied in texture and found to belong to six textural classes on the basis of their mechanical composition. The significant negative and exponentially correlation between Ksat and the silt + clay contents indicates that efficient water management practices require correct knowledge of soil textural fractions. The hydraulic properties of the soils including saturated hydraulic conductivity, soil moisture at field capacity, permanent wilting point and maximum water holding capacity had significant correlation with silt + clay content, bulk density and soil organic carbon content of the soils (Table 2). The correlation study revealed that the hydraulic properties are predominantly influenced by mechanical composition of the soils. Influence of $\mathrm{pH}$, soluble salts and $\mathrm{SAR}$ was found non-significant on hydraulic properties of the soils. The results of the study present the quantitative determination of the hydraulic properties of the soils spread over the different locations of the State and might be used in adopting suitable and efficient water management techniques and practices in the present scenario of limited water resources in arid and semi-arid regions of the State for sustainable agriculture.

\section{References}

Basile, A., Coppola, A., De Mascellis, R. and Randazzo, L. 2006. Scaling approach to deduce field unsaturated hydraulic properties and behavior from laboratory measurements on small cores. Vadose Zone Journal 5, 1005-1016.

Beare, M.H., Cabrer, M.L., Hendrix, P.F. and Coleman, D.C. 1994. Aggregateprotected and unprotected organic matter pools in conventional- and notillage soils. Soil Science Society of America Journal 58, 787-795.

Cornelis, W.M., Ronsyn, J., van Meirvenne, M. and Hartmann, R. 2001. Evaluation of pedotransfer functions for predicting the soil moisture retention curve. Soil Science Society of America Journal 65, 638-648.

Deb, S.K. and Shukla, M.K. 2012. Variability 
of hydraulic conductivity due to multiple factors. American Journal of Environmental Science 8, 489-502.

Dec, D., Dorner, J., Fazekas, O.B. and Horn, R. 2008. Effect of bulk density on hydraulic properties of homogenized and structured soils. Journal of Soil Science and Plant Nutrition 8, 1-13.

Downie, A., Crosky, A. and Munaro, P. 2009. Physical properties of biochar. In: Lehmann, J., Joseph, S. Biochar for Environmental management: Science and Technology, Earthscan, pp 13-29.

Fereres, E. and Soriano, M.A. 2007. Deficit Irrigation for Reducing Agricultural Water Use. Journal of Experimental Botany 58, 147-159.

Halfmann, D.M. 2005. Management system effects on water infiltration and soil physical properties. Texas Tech University, Faculty of Soil science. pp 9-11, 35, 85, 92

Hillel 1982. Field testing of Soil moisture model simulating water table fluctuations. Soil Science Society of America Journal 46, 396-404.

Hudson, B.D. 1994. Soil organic matter and available water capacity. Journal of Soil and Water Conservation 49, 189-194.

Hugar, G.M., Sorganvi, V. and Hiremath, G.M. 2012. Effect of organic carbon on soil moisture. Indian Journal of Natural Sciences 3, 1191-1198.

Jarvis, N., Koestel, J., Messing, I., Moeys, J. and Lindahl, A. 2013. Influence of soil, land use and climatic factors on the hydraulic conductivity of soil. Hydrology and Earth System Science 17, 5185-5195.

Kar, G., Kumar, A., Panigrahi, S., Dixit, P.R. and Sahoo, H.N. 2017. Particle size distribution, soil organic carbon stock and water retention of some upland use system of odisha and assessing their interrelationship. Journal of Indian Society of Soil Science 65, 48-53.
Lal, R. and Shukla, M.K. 2004. 'Principles of soil physics'. Marcel Dekker Inc. NewYork, Pp. 405- 411.

Lee, D.H. 2005. Comparing the inverse parameter estimation approach with pedotransfer function method for estimating soil hydraulic properties. Geosciences Journal 9, 269-276.

Leij, F.J., Romano, N., Palladino, M., Schaap, M.G. and Coppola, A. 2004. Topographical attributes to predict soil hydraulic properties along a hillslope transect. Water Resources Research 40, $1-15$.

Nimmo, J.K. 1997. Modelling structural influences on the soil water retention. Soil Science Society of America Journal 61, 712-719.

Olorunfemi, I.E. and Fasinmirin, J.T. 2011. Hydraulic conductivity and infiltration of soils of Tropical Rain Forest Climate of Nigeria. In 'Proceedings of the Environmental Management Conference', Federal University of Agriculture, Abeokuta, Nigeria, pp. 397-413.

Papanicolaou, A.N., Elhakeem, M., Wilson, C.G., Burras, C.L., West, L.T., Lin, H., Clark, B. and Oneal, B.E. 2015. Spatial variability of saturated hydraulic conductivity at the hillslope scale: Understanding the role of land management and erosional effect. Geoderma 243, 58-68.

Piper, C.S. 1966. Soil and Plant Analysis. Hans Publishers, Bombay.

Rawls, W.J., Nemes, A. and Pachepsky, Y.A. 2005. Effect of soil organic matter on soil hydraulic properties, In: Development of Pedotransfer Functions in Soil Hydrology (Pachepsky and Rawls, Ed.), Elsevier, Amsterdam, pp. $95-114$

Rawls, W.J., Pachepsky, Y.A., Ritchie, J.C., Sobecki, T.M. and Bloodworth, $\mathrm{H}$. 2003. Effect of soil organic carbon on 
soil water retention. Geoderma 166, 6176.

Reicosky, D.C. 2005. Conservation agriculture: Zero tillage impact on soil organic matter. Proc. 27th Annual Zero Tillage and Winter Wheat Workshop, Brandon, Canada. 1-2 Feb., 2005. Manitoba-North Dakota Zero Tillage Farmers Association, pp. 39-47.

Reynolds, W.D. 2000. Comparison of tensiometer infiltrometer, pressure infiltrometer and soil core estimation of saturated hydraulic conductivity. Soil Science Society of America Journal 64, 478-484.

Richard, L.A. 1954. Diagnosis and Improvement of Saline and Alkali Soils. U.S. Salinity Laboratory, U.S. Department of Agriculture, Hand Book 60.

Shwetha, P. and Varija, K. 2015. Soil water retention curve from saturated hydraulic conductivity for sandy loam and loamy sand textured soils. Aquatic Procedia 4, $1142-1149$.

Singh, A., Phogat, V.K., Dahiya, R. and Batra, S.D. 2014. Impact of long-term zero till wheat on soil physical properties and wheat productivity under rice-wheat cropping system. Soil \& Tillage Research 140, 98-105.

Singh, A.P., Singh, A., Tiwari, H.L. and Dwivedi, P.K. 2011. The effect of salts of the hydraulic conductivity of the saline alkali soil. Indian Journal of Scientific Research 4, 117-119.

Six, J., Bossuyt, H., Degryze, S. and Denef, K. (2004) A history of research on the link between (micro) aggregates, soil biota and soil organic matter dynamics. Soil \& Tillage Research 79, 1-31.

Vereecken H, Maes J. and Feyen J. 1990. Estimating unsaturated hydraulic conductivity from easily measured soil properties. Soil Science 149, 1-12.

Walkley, A. and Black, I.A. 1934. An examination of the Degtjareff method for determining soil organic matter and a proposed modification of the chromic acid titration method. Soil Science 37, 29-38.

Yazdanpanah, N., Mahmoodabadi, M. and Cerdia, A. 2016. The impact of organic amendments on soil hydrology, structure and microbial respiration in semiarid lands. Geoderma 266, 58-65.

\section{How to cite this article:}

Seema, Rita Dahiya and Phogat, V.K. 2019. Investigation of Hydraulic Properties of Soils Varying in Texture, Organic Carbon and Soluble Salt Contents of Arid and Semi-arid Regions. Int.J.Curr.Microbiol.App.Sci. 8(04): 2827-2838. doi: https://doi.org/10.20546/ijcmas.2019.804.330 